Journal of

\title{
Food and Health Science
}

E-ISSN 2149-0473

\section{PESTICIDE RISKS OF SEAFOOD IN TURKEY}

\section{Şafak ULUSOY, Özkan ÖZDEN}

İstanbul University, Faculty of Fisheries, Department of Seafood Processing and Technology, Istanbul/Turkey

Received: 10.10 .2014

Accepted: 06.12.2014

Published online: 20.12.2014
Corresponding author:

Şafak ULUSOY, İstanbul University, Faculty of Fisheries, Department of Seafood Processing and Technology, Ordu Caddesi No: 200, Laleli-Fatih, 34134 Istanbul/Turkey

E-mail: safak@istanbul.edu.tr

\begin{abstract}
:
Turkey is a rich country in terms of seas and inland water sources. The aquatic ecosystems in Turkey are threatened by the agricultural activities and pesticide contamination. In parallel to the world, the use of pesticides began in the 1940s in Turkey. In the beginning of 1970's some pesticides have prohibited by reason of their accumulation to environment and food chains, toxic effects on non-target organisms. Pesticides can easily be included to the food chain in the aquatic environment which causes many risks on human health and food safety. There are still not enough data on the concentrations of pesticides in seafood and fish in Turkey.
\end{abstract}

\section{Keywords:}

Pesticide, Seafood, Fish, Food safety, Turkey 


\section{Introduction}

Pesticide is generally used to describe chemical and biological products which have been specifically developed to control pests, weeds and diseases particularly in the production of food (FAO, 2002). There are several classes of pesticides including insecticides (protect against and/or control insect infestations), fungicides (protect against and/or control the spread of fungal diseases), herbicides (control the competing effects of weeds), molluscicides (control the destructive effects of slugs and snails) and rodenticides (control the activities of rats and mice) (Hamilton and Crossley, 2004).

Pesticides are divided into three main classes according to their chemical structures:

- $\quad$ Organochlorine pesticides
- $\quad$ Organophosphorous pesticides
- $\quad$ Herbicide acids: 2,4-D, 2,4,5-T
- $\quad$ Urea herbicides: dinuron, linuron
- $\quad$ S-triazines: atrazine, simazine
- $\quad$ Oyrethroids
pounds

Organochlorine pesticides are insecticides, which are usually obtained with chlorination of organic substances including carbon-hydrogen and chlorine. They are only insoluble in water, but they do not evaporate easily. Due to their high persistence and lipophilicity, they can cause damage in living organisms by accumulating in fatty tissues. Additionally, they cause environmental pollution due to they are more resistant to naturel conditions than the other groups. Therefore, they highly damage the environment, besides their benefits. This group includes major pesticides such as DDT, $\mathrm{HCH}$ and its isomers $[\alpha-\mathrm{HCH}, \beta-\mathrm{HCH}, \gamma-\mathrm{HCH}$ (lindane)], heptachlor, dieldrin, aldrin, endosulfan, toxaphene and methoxychlor (A $\breve{g c a}, 2006$; Chopra et al., 2010; Erdoğan, 2010).

Polychlorinated biphenyls (PCBs) are chlorinated organic compounds which were produced for industrial purposes in 1930s. PCBs are persistent environmental substances, liphophilic and for certain congeners, bioaccumulative due to their relatively low reactivity and high hydrophobicity. They are found in the sediment by connecting to organic waste. PCBs can contaminate environment, seafood and threat human health as well as OCPs (Bocio et al., 2003; Güvenç and Aksoy, 2007; Seyran and Erişir, 2008).

In recent years, many pesticides of different chemical compositions are currently used for agricultural and control purposes and maintain the availability of low cost all over the world and the use of them has increased rapidly in the last fifty years (Bulut et al., 2010; Mathur et al., 2010; Wilson and Otsuki, 2004). However, chemical pesticides are usually not target-specific and therefore, may cause many problems to non target species. Their transportation is rather easily among air, water, land and span boundaries of programs, geography and generations. Many of them are quite persistent for long periods in the environment. Especially, OCPs are generally characterized by strong persistency, bioconcentration through food webs, and long-range transport. They may impart toxicity to the groundwater and cause harmful health effects. These problems include various toxic effects on immune, nervous, endocrine and reproductive systems, potential carcinogenic effects, brain damage in children, lowered IQ and permanent kidney damage; human pesticide poisonings, fish and bird deaths, pesticide resistance, contamination of food and water with pesticide residues.

Pesticide residues are unused pesticides and also pesticide's degradation product and metabolites in the various inter-compartments. They are transformed into a range of different products due to their susceptibility to biotic and abiotic degradation. Pesticides residues are generally characterized due to lipophilic and hydrophobic properties. Therefore, they persist in the environment and bioaccumulate in food chains, and impose various toxic effects in marine organisms including fish, seafood, planktons etc. Entrance of them into food chain are by atmospheric transport of emissions and their deposition on plants, soils and water. Thus entering the food chain, pesticides residues accumulate and concentrate in the fat of animal products, fish and shellfish. For these reasons, adverse effects on the aquatic ecosystem and human health of pesticides have an important role in environmental and public health problems in the world (Aktümsek et al., 2002; Chopra et al., 2010; Çakıroğulları et al., 2011; Harvey et al., 2008; Kalyoncu et al., 2009; Llobet et al., 2003; Özçelik et al., 2011; Sweilum, 2006; Turgut, 2003; Saler, 2006). 


\section{Pesticides in Turkey}

Agriculture is one of the leading sectors in the Turkish economy. Total cultivated agricultural land is 20539 hectares, as total agricultural land is 38247 hectares in 2011 in Turkey. Despite the decreasing share of gross domestic product, agricultural production has been increasing since 2000 . The amount of agricultural production in 2009 was TRY 79 billion (TÜIKK, 2011; Turkish Agriculture Industry Report, 2010). The usage of pesticides play a very important role in our country in order to increase the amount of product obtained per unit area in these agricultural areas as well as in other countries. The world pesticide consumption is approximately 3 million tons, $0.6 \%$ is the share of Turkey. Although pesticide use per hectare in Turkey is very low compared to developed countries, the most consumed pesticides have significant environmental and health risks. Uncontrolled and unconscious use of pesticides in agriculture affect non-target organisms, which cause deterioration of ecological balance by contaminated land, inland waters and sea (Başpınar et al., 2010; Kaya, 2007; Yeşil and Ögür, 2011). The usage of pesticides in Turkey started with use of DDT in the 1960s after II World War. Even after the ban of OCPs including aldrin, endrin, DDT, dieldrin, hexachlorocyclohexane (HCHs), heptachlor, chlordane and toxaphene between 1971 and 1989, they are still being used illegally in some regions (DPT 2001; Okay et al., 2011). Unconscious and dangerous practices of them are very common, although Turkey is country that uses very little pesticide now (Bulut and Tamer, 1996). Pesticide consumption values of Turkey are shown in Table 1 according to 2008 data. The usage of PCBs in Turkey was restricted in the industry in 1973 and their usage in open systems was strictly banned on January 11996 (Güvenç and Aksoy, 2007). Regulation about the licensing of pesticides and similar substances came into force on 17 February 1999 in Turkey.

Use of total annual pesticide was 33,000 tons between 1998 and 2004 in Turkey (Güvenç and Aksoy, 2007; Okay et al., 2009). According to the data 2008, the amount of the use of total insecticides and the other total pesticides were 10827.00 and 12137.00 tons, respectively (Food and Agriculture Organization of the United Nations [FAO], 2011). Marmara, Aegean and Mediterranean Regions of Turkey are major areas where pesticides are most used. As shown Figure 1, insecticides are the most consumed group in these pesticides (Arslan, 2009; DPT, 2008).

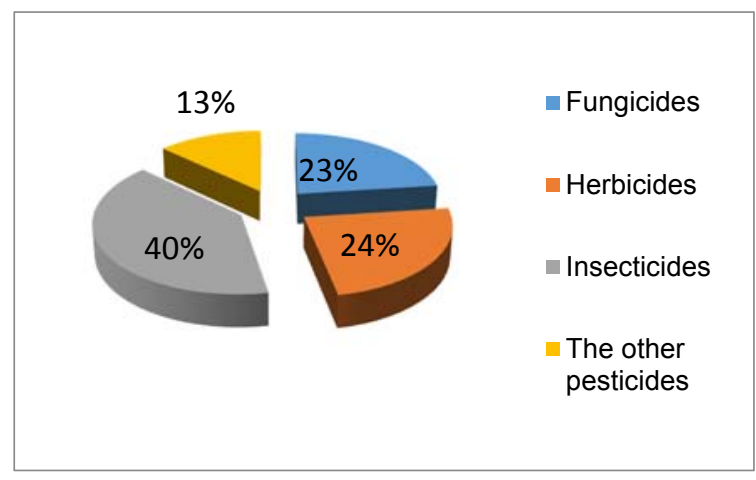

Figure 1. Pesticide usage amount of Turkey according to the groups in 2004 (DPT, 2008)

Table 2 shows some pesticides prohibited in Turkey. The usage, production and importation of most pesticide components were prohibited by the reason of toxicological and ecotoxicological risks (DPT, 2001). Figure 2 shows the regional agricultural production in Turkey (DPMARA, 2011).

The most commonly used pesticides in Turkey carries significant risks for the environment and human health, despite the pesticide consumption in Turkey is less than the world average (Delen et al., 2005). There are claims about banned or restricted pesticides are still being used, since pesticides are still determined high concentrations in aquatic ecosystems and seafood (Ayas, 2007).

\section{Seafood and Pesticides}

Today, the widespread use of pesticides has resulted in the presence of their residues in the aquatic environment (Özçelik et al., 2011). Large quantities of pesticides reside in coastal sediments, open-ocean waters and freshwater ecosystems. Pesticides residues reach the aquatic environment through direct runoff, leaching, careless disposal of empty containers, uncontrolled discharge of contaminated industrial equipment washings, etc. (Atamanalp and Yanık, 2001; Ferrante et al., 2010; Smith and Gangolli, 2002). Distribution of a pesticide in the environment varies according to its chemical structure, physical properties, formulation type, application method, the climate and agricultural conditions (Topçu Sulak et al., 2012). 


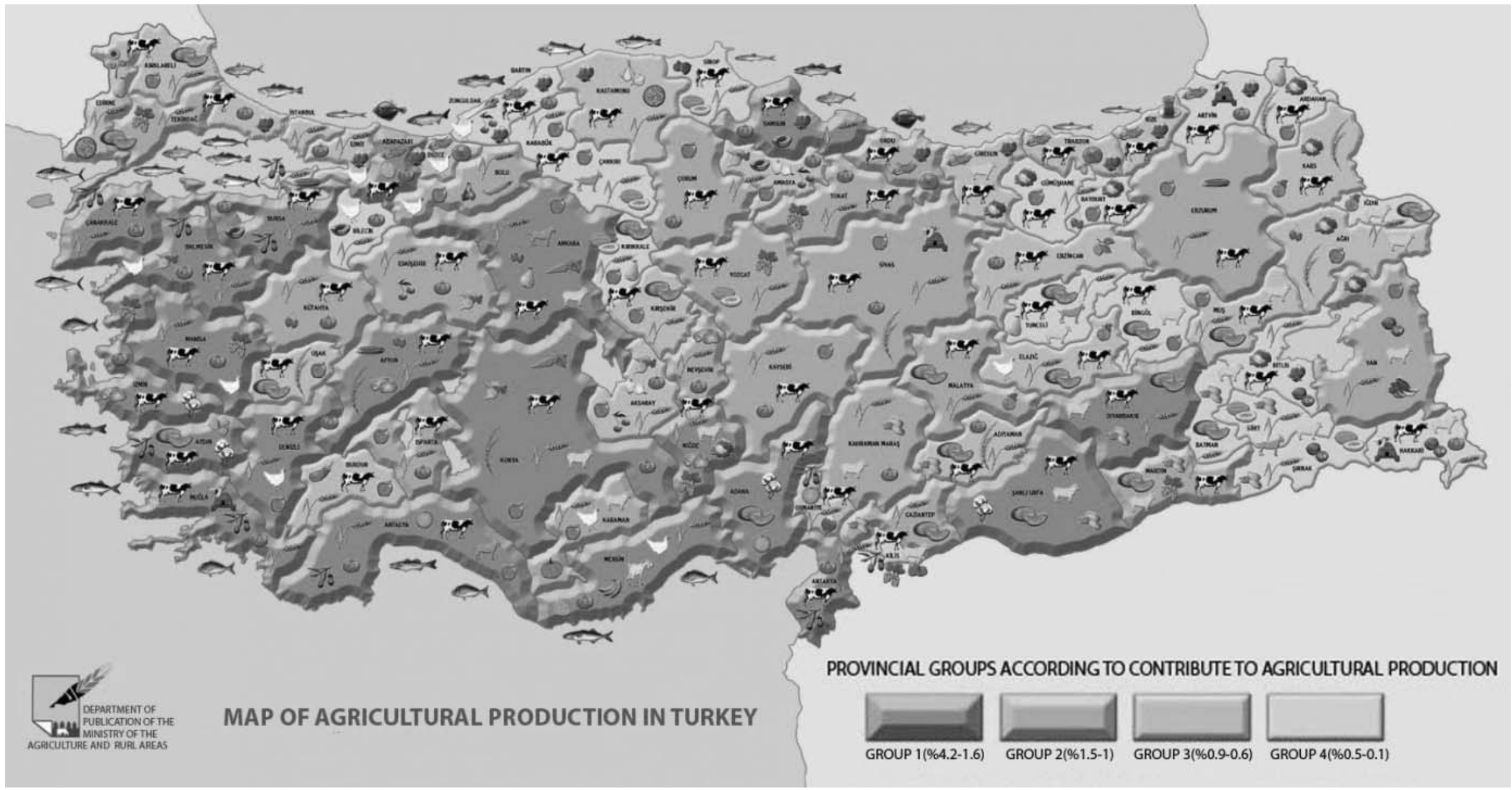

Figure 2. Map of agricultural production of Turkey (Department of Publication of the Ministry of the Agriculture and Rurl Areas, 2011). 
Table 1. Pesticides Consumption in Turkey (tonnes) (DPT, 2008)

\begin{tabular}{llllllll}
\hline & 1998 & 1999 & 2000 & 2001 & 2002 & 2003 & 2004 \\
\hline Insecticides & 10.450 & 9.089 & 11.788 & 11.544 & 9.159 & 11.492 & 13.793 \\
Herbicides & 5.743 & 7.408 & 6.958 & 6.192 & 7.416 & 11.352 & 8.707 \\
Fungicides & 8.613 & 7.036 & 7.777 & 5.909 & 8.075 & 9.859 & 10.394 \\
Others & 9.605 & 8.058 & 7.025 & 4.691 & 6.667 & 3.221 & 2.549 \\
Total & 34.411 & 31.591 & 33.548 & 28.336 & 31.317 & 35.924 & 35.443 \\
\hline
\end{tabular}

Table 2. Pesticides prohibited in Turkey

\begin{tabular}{ll}
\hline Name & Prohibited date \\
\hline Dieldrin & 1971 \\
Aldrin & 1979 \\
Endrin & 1979 \\
Lindane & 1979 \\
Heptachlor & 1979 \\
Chlordane & 1979 \\
E-Parathion & 1979 \\
2,4,5-T & 1979 \\
2,4,5-T & 1979 \\
Chlordimeform (methoxyethylmercury & 1979 \\
Mercury & 1982 \\
chloride,phenylmercuryacetate,phenylmercury chlorid) & \\
Arsenical chemicals & 1982 \\
Chlorbenzilate & 1982 \\
DDT (Limitation 1978) & 1985 \\
BHC (Limitation 1978) & 1985 \\
Fluorodifen & 1987 \\
Chlorpropylate & 1987 \\
Dinoseb & 1988 \\
Daminozide(Alar 85) & 1989 \\
Toxaphene & 1989 \\
Zineb & 1991 \\
Azinphos Ethyl & 1996 \\
\hline
\end{tabular}

(DPT, 2001)

Pesticide residues may enter a marine organism in several ways: direct uptake from contaminated water through dermis or gills, consumption of contaminated sediment, or consumption of previously contaminated organisms. Pesticides are also applied directly to water to control unwanted algae and invertebrates (Kaya, 2007). It is generally known that the resistant variety residues which are identified in marine environment move to the sea through the atmosphere (Figure 3).

Once these contaminants enter an organism, they tend to remain in the animal tissues and may build up with subsequent exposures. As contaminated organisms are consumed, contaminants may be passed from one organism to the next (Barlas et al., 2000; Harvey et al., 2008). 


\section{Transition of Pesticides to Seafood}

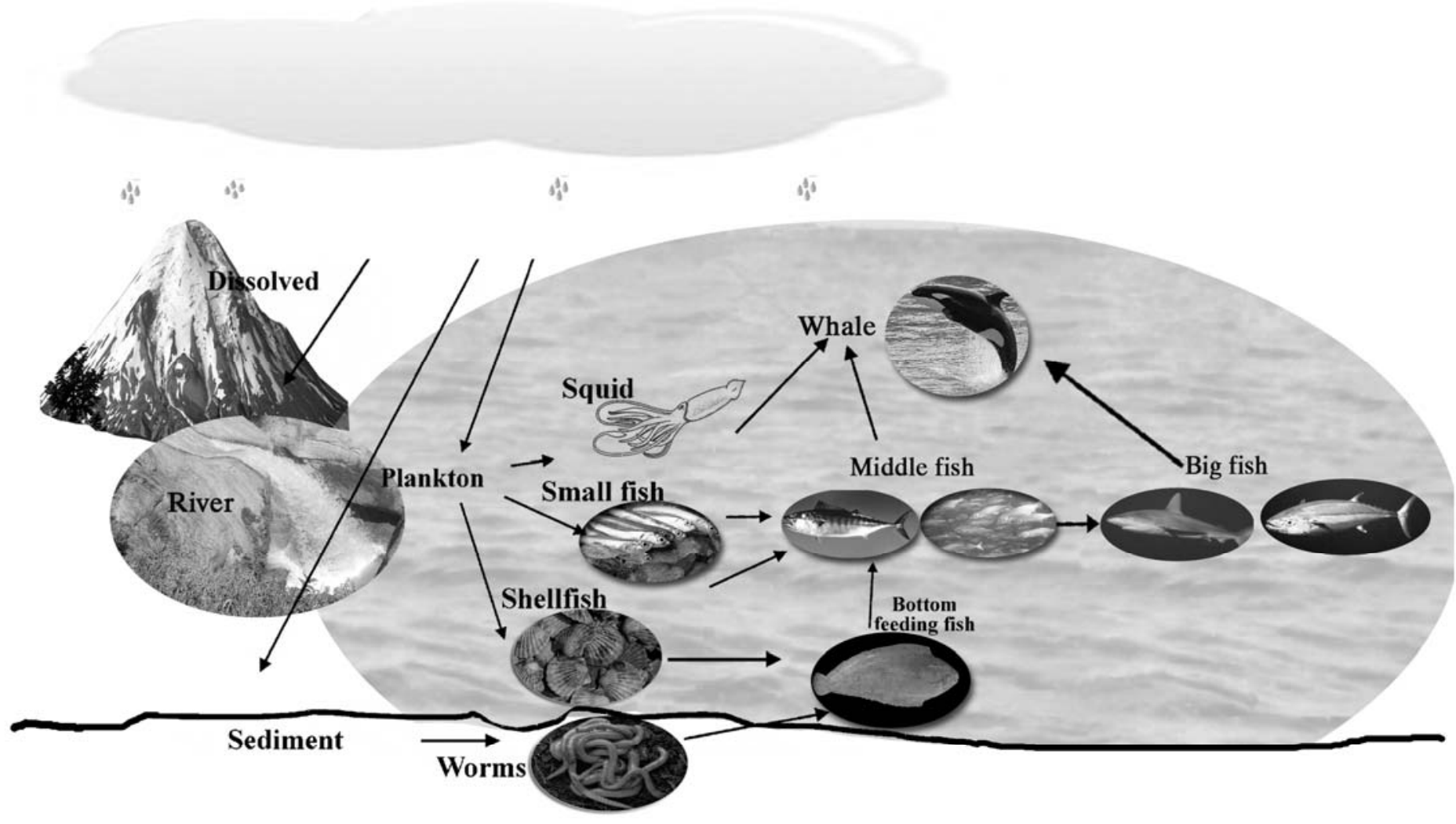

Figure 3. Moving of organochlorine compounds from air, river, sewage to marine environment (modified by Smith and Gangolli, 2002).

Organochlorine pesticides containing DDT, BHC and its isomers, endosulfan, aldrin, methoxychlor, chlordane, endrin, heptachlor, and PCBs are persistent in the environment and are also capable of long-range transport and bioaccumulation in human and other animal tissues. These persistent highly synthetic compounds accumulate in the organs and tissues of living different organisms passing through the biological phospholipid membranes. Thus, they are conveyed through the food chain to humans (Chopra et al., 2010; Syasina, 2003). These compounds have low water solubility, particularly in seawater and they are lipophilic with high octanol/water partition coefficients (log $\mathrm{P} \mathrm{o} / \mathrm{w})$. Thereby, fish and shellfish represent an important source of OCP intake (Smith and Gan- golli, 2002; Takazawa et al., 2008). These chemical residues usually concentrate in tissues with high fatty content or in muscle, or in specific organ systems, depending on the lipophilic nature of the specific chemical and how the chemical is metabolized (Barlas et al., 2000; Harvey et al., 2008). These liphophilic, persistent pollutants accumulate in these fat deposits and can cause toxic effects. The distribution of these chemicals in aquatic environment is dynamic, complex and depends on the seasonal variations and local conditions (Smith and Gangolli, 2002). Therefore, aquatic ecosystems play an important role in major source of human exposure to organochlorine compounds with food chain (Ferrante et al., 2010; Takazawa et al., 2008). 
PCBs are found in sediment by connecting to organic waste due to lipophilic properties of them. Thus, they accumulate in organisms which live in sediment. PCBs enter the food chain by fish and other seafood eat these aquatic organisms. Therefore, aquatic organisms strongly accumulate PCBs from water and food sources. Despite some PCBs are metabolized by fish, some of them accumulate in their fatty tissue. PCBs accumulation in fatty tissue depends on the amount and duration of exposure, chemical structure of the compound. PCBs which contain high amounts of chlorine tend to accumulate more than the other pesticide which contain low amount of chlorine. PCBs which contain low chlorine amount are disposed faster by metabolism. The accumulation of residues in any aquatic organism in the marine environment varies according to the organism occupies in marine food chain and from country to country. Despite the low consumption of fish and seafood in human diet, they are major sources of these compounds into the human body. There have been confirmed that most of these compounds affects human health in the world (Boscolo et al., 2007; Çakıroğulları et al., 2011; Güvenç and Aksoy, 2007). Concentrations of pesticide residues in the fish are about 1000-10000 times higher than in water. Although seafood consumption is very useful for human health, seafood consumption has been reported as an important route of human exposure to a variety of chemical contaminants. So, fish is an indicator because of containing high concentrations of these substances. The amount of pesticide residues varies according to the species of fish and their sizes (Aktümsek et al., 2002; Barlas et al., 2000; Storelli, 2008).

\section{Seafood Safety Related to Pesticides in Turkey}

Today, nutrition is one of the most important problems in the growing world population. Food safety is a significant concern for food processors and consumers. Therefore, the use of pesticides has increased for getting more efficiency in agricultural areas. Although pesticides provide significant benefits, there are serious concerns regarding their use in the world because of the chemical stability of these compounds, their high lipid solubility and toxicity to humans and animals (Ezemonye et al., 2009; Karakaya and Boyraz, 1992; Mead et al., 1999). Their lipophilicity and resistance to degradation leads to a lifelong accumulation of these compounds in human tissues and fluids (Kurşun and Mor, 2008).
Food consumption is an important pathway for exposure to pesticide contaminants and these exposures to pesticides in food may pose a public health risk (Liu et al., 2010). Organic pollutants in food accumulate in biological organisms especially fish and meat because of lipophilic and stability environment properties (Ağca, 2006). Seafood usually contains residues of pesticide and is often considered to be a major source of intake of these contaminants for humans (Falandysz et al., 2004). Pesticides such as OCPs and polychlorinated biphenyls adversely affect environmental system and human health, and therefore, clarifying the residual concentrations of OCPs in aquatic biota is necessary to assess their risk to human health and to protect natural ecosystems (Takazawa et al., 2008). When pesticides are used over the recommended doses, they can leave too much residue in foodstuffs (Karakaya and Boyraz, 1992). Levels of pesticide residues in foodstuffs should not cause harm to human, animal and environmental health. Therefore, to know amount of pesticide residue is important for human health and export food products. The tolerance limit of produced any new pesticide must be determined with pharmacological and toxicological examinations before being released (Kınık, 2002). Developing countries prefer to use cheap chemicals such as DDT, $\mathrm{HCH}$, $\mathrm{BCH}$. That's why residues in food, contamination of environment and exposure of public are higher. They also entail risks to public health (Carvalho, 2006). Although consumption of pesticides is very low in our country, unconscious and dangerous practices are very common (Bulut ve Tamer, 1996). Table 3 shows maximum residue levels of some pesticides in all products according to Turkish Food Codex. Some pesticide values of seafood determined in Turkey are shown in Table 4 and Table 5. The PCBs levels in the studies were not hazardous to people. The maximum limit value of sum of PCB 28, PCB 52, PCB 101, PCB 138, PCB 153 and PCB 180 in fish meat is $75 \mathrm{ng} / \mathrm{g}$ according to Turkish Food Codex (Turkish Food Codex, 2011). The maximum residue limits of OCPs have not been determined for fish and seafood yet in the Turkish Food Codex and European Commission Directive. Hence, these values could not be evaluated in terms of food safety and public health (Aksoy et al., 2012).

Turkey is a country surrounded by seas on three sides and is considered to be affected by the risks of pesticides due to having large agricultural area and 26.2 million hectares of land in terms of sea, 
lakes, ponds and streams (Agricultural and Food Panel, 2003; Başçınar et al., 2008).

These aquatic ecosystems have been contaminated by persistent pollutants of agricultural and industrial origin (Erkmen and Kolankaya, 2006). So, the determination of presence of pesticides in fish and seafood is important not only from ecological but also from public health perspective (Kalyoncu et al., 2009).

Although usage of OCPs has been prohibited in most countries including Turkey, they were detected in surface waters, sediments and suspended solid more than many years after they were prohibited (Turgut, 2003).

Studies on pesticide residues in seafood in Turkey are very low (Delen et al., 2005). As a result, the levels of pesticide on seafood should be done consistently and their results should be published in reports. The ministry of government should monitor the levels of pesticides regularly and evaluate the results properly. Both producers and consumers should be made conscious in order to prevent pesticide contamination in fish and seafood.

Pesticide usage should be controlled to ensure food safety for public health in Turkey, as well. Low risk and environmentally friendly pesticides should be used just as in the case of Europe and America.

Food consumption is the most important factor affecting human health in the life span. Health problems are one of the most important issues in the world. Hence, this is the most sensitive over the society. Seafood is expected to be most important protein source of the future with increasing global warming. In this sense, a healthy supply of seafood is becoming more important for countries and societies. In this field, marine contamination is an increasing major problem due to developing industry and modern farming methods. Therefore, pesticide consumption limit values and, how often and how much amount of pesticides got the consumer in seafood nutritional regime have great importance in the most of the countries. Intensive consumption of seafood will lead to various toxicity and carcinogenic effects depending on the kind of pesticide being exposed.

\section{Conclusion}

In terms of public health, a regular monitoring is required not only for marine and aquatic areas, but also for the whole environment (including the agricultural sector) for pesticide contamination in Turkey. Informing consumers by the Ministry with one or two annual reports will help the formation of properly accessible references regarding world nutrition literature. Thus, this will also accelerate to take necessary measures. Open access to all this information on the internet is also very important.

Agricultural and industrial usage policies of pesticides, common monitoring programs should be established by countries that contain or limit marine and inland waters against the pollution. Consumer awareness trainings are also required for the implementation of all these procedures in a healthy way. It means that self-control system of all individuals living in these countries will create.

Table 3. Maximum residue levels of some pesticides in all products (Turkish Food Codex 2009).

\begin{tabular}{ll}
\hline Compound & Amount (ng/g) \\
\hline Heptachlor & 10 \\
Endrin & 10 \\
$\sum$ DDT & 50 \\
HCB & 10 \\
Lindane & 10 \\
Chlordane (total of cis and trans chlordane) & 10 \\
\hline
\end{tabular}


Journal abbreviation: J Food Health Sci

Table 4. OCPs concentrations in marine organisms from various geographical locations in Turkey (ng/g)

\begin{tabular}{|c|c|c|c|c|c|c|c|c|c|c|c|c|c|}
\hline Sampling sites & Species analyzed & $\begin{array}{l}\text { Aldrin } \\
\mathrm{ng} / \mathrm{g}\end{array}$ & $\begin{array}{l}\text { Heptachlor } \\
\text { Epoxide } \\
\mathrm{ng} / \mathrm{g}\end{array}$ & $\begin{array}{l}\text { Dieldrin } \\
\mathrm{ng} / \mathrm{g}\end{array}$ & $\begin{array}{l}\text { Endrin } \\
\mathrm{ng} / \mathrm{g}\end{array}$ & $\begin{array}{l}\text { pp'-DDT } \\
\text { ng/g }\end{array}$ & $\begin{array}{l}\text { pp'-DDD } \\
\text { ng/g }\end{array}$ & $\begin{array}{l}\text { pp'-DDE } \\
\text { ng/g }\end{array}$ & $\sum_{\mathrm{ng} / \mathrm{g}}$ DDT & $\begin{array}{l}\mathbf{H C B} \\
\mathrm{ng} / \mathrm{g}\end{array}$ & $\begin{array}{l}\text { Lindane } \\
\mathrm{ng} / \mathrm{g}\end{array}$ & $\begin{array}{l}\text { Endosulfan } \\
\text { sulphate } \\
\mathrm{ng} / \mathrm{g}\end{array}$ & References \\
\hline $\begin{array}{l}\text { Istanbul Markets } \\
\text { (Is the largest city in Turkey) }\end{array}$ & Canned fish (Sardine & & - & $0.4-0.5$ & 0.2 & $0.3-0.5$ & $4.1-1$ & $11.1-6.2$ & $17.1-7.6$ & $0.3-1.1$ & - & - & Özden et al., 2001 \\
\hline $\begin{array}{l}\text { Istanbul Markets } \\
\text { (Is the largest city in Turkey) }\end{array}$ & $\begin{array}{l}\text { Canned fish } \\
\text { (Anchovy) }\end{array}$ & - & - & $1.4-0.3$ & 0.5 & $1.8-1.7$ & $9.7-4.0$ & $13.6-7.5$ & $28.2-13.8$ & $1.1-0.4$ & - & - & Özden et al., 2001 \\
\hline $\begin{array}{l}\text { Istanbul Markets } \\
\text { (Is the largest city in Turkey) }\end{array}$ & $\begin{array}{l}\text { Canned fish } \\
\text { (Pelamide) }\end{array}$ & - & - & 2.1 & nd & $0.1-0.03$ & 72.3 & 6.9 & 146.6 & 2 & - & - & Özden et al., 2001 \\
\hline $\begin{array}{l}\text { Istanbul Markets } \\
\text { (Is the largest city in Turkey) }\end{array}$ & Canned fish (Trout) & - & - & 0.2 & nd & $0.1-0.03$ & 2.4 & 3.7 & 8.3 & 16.4 & - & - & Özden et al., 2001 \\
\hline Istanbul Bosporus & $\begin{array}{l}\text { Mytillus } \\
\text { galloprovincialis }\end{array}$ & - & - & 0.4 & 0.8 & 1 & 7.4 & 4.6 & 130 & 0.2 & - & - & Özden et al., 2002 \\
\hline Sir Dam Lake & Cyprinus carpio & - & - & - & - & nd-1.23 & $0.35-13.0$ & $4-156$ & - & $0.03-0.41$ & nd- 0.67 & - & Erdogrul et al., 2005 \\
\hline Marmara Sea & Anchovy & - & - & - & - & 23.60 & 79.54 & 92.34 & - & 4.92 & - & - & Coelhan et al., 2006 \\
\hline Marmara Sea & Horse Mackerel & - & - & - & - & 67.55 & 146.45 & 144.18 & - & 6.91 & - & - & Coelhan et al., 2006 \\
\hline Marmara Sea & Young Bluefish & - & - & - & - & 85.86 & 203.72 & 211.68 & - & 11.15 & - & - & Coelhan et al., 2006 \\
\hline İzmit Gulf & FWhiting) & - & - & - & - & - & - & - & $46.74-3377.50$ & - & - & - & Çakıroğulları, 2006 \\
\hline İzmit Gulf & Horse Mackerels & - & - & - & - & - & - & - & $42.85-2086.97$ & & & & Çakıroğulları, 2006 \\
\hline Meriç Delta & Cyprinus carpio & nd & $3.041-1.25$ & $17.78-1.35$ & $31.5-8.06$ & $52.45-2.68$ & nd- -8.83 & $14.03-2.2$ & $6.14-62.25$ & - & $2.49-0.49$ & $40.4-4.23$ & $\begin{array}{l}\text { Erkmen and } \\
\text { Kolankaya, } 2006\end{array}$ \\
\hline $\begin{array}{l}\text { The mid Black Sea coast of } \\
\text { Turkey }\end{array}$ & $\begin{array}{l}\text { Mytilus } \\
\text { galloprovincialis }\end{array}$ & $<0.12-0.879$ & $<0.05-2.419$ & $<0.12$ & $<0.15-7.782$ & $<0.18$ & $<0.18-14.015$ & $<0.12-0.23$ & - & $<0.10-0.364$ & $<0.12-1.511$ & $<0.10-0.80$ & Ozkoc et al. 2007 \\
\hline $\begin{array}{l}\text { Konya Markets (Anatolia } \\
\text { part) }\end{array}$ & Horse Mackerel & 16.1 & 16.3 & 12.6 & 3.26 & 4.14 & nd & 19.2 & - & - & 5.4 & - & Kalyoncu et al., 2009 \\
\hline $\begin{array}{l}\text { Istanbul Strait in the Marmara } \\
\text { Sea }\end{array}$ & $\begin{array}{l}\text { Mytilus } \\
\text { galloprovincialis }\end{array}$ & $0.00288-0.13$ & $0.0162-0.0764$ & $0.0554-0.386$ & $0.0418-0.0503$ & - & - & - & - & $0.00833-0.116$ & - & - & Okay et al. 2011 \\
\hline
\end{tabular}


Journal abbreviation: J Food Health Sci

Table 5. PCB concentrations in marine organisms from various geographical locations in Turkey (ng/g)

\begin{tabular}{|c|c|c|c|c|c|c|c|c|}
\hline Sampling sites & Species analyzed & $\begin{array}{l}\text { PCB-28 } \\
\text { ng/g }\end{array}$ & $\begin{array}{l}\text { PCB-52 } \\
\mathrm{ng} / \mathrm{g}\end{array}$ & $\begin{array}{l}\text { PCB-180 } \\
\text { ng/g }\end{array}$ & $\begin{array}{l}\text { PCB-138 } \\
\text { ng/g }\end{array}$ & $\begin{array}{l}\text { PCB-153 } \\
\text { ng/g }\end{array}$ & $\begin{array}{l}\text { Sum PCBs } \\
\mathrm{ng} / \mathrm{g}\end{array}$ & References \\
\hline $\begin{array}{l}\text { Istanbul Markets (Is the largest } \\
\text { city in Turkey) }\end{array}$ & Canned fish (Sardine) & $0.2-0.6$ & $0.3-1.5$ & $0.3-0.6$ & 1.3 & $0.5-1$ & - & Özden et al., 2001 \\
\hline $\begin{array}{l}\text { Istanbul Markets (Is the largest } \\
\text { city in Turkey) }\end{array}$ & Canned fish (Anchovy) & $0.3-0.8$ & $0.2-7.9$ & $0.5-1$ & $0.5-1.9$ & $1-2.5$ & - & Özden et al., 2001 \\
\hline $\begin{array}{l}\text { Istanbul Markets (Is the largest } \\
\text { city in Turkey) }\end{array}$ & Canned fish (Pelamide) & 0.3 & nd & 1.8 & 4.2 & 5.9 & - & Özden et al., 2001 \\
\hline Istanbul Bosporus & Mytillus galloprovincialis & nd & $0.1-1.5$ & 0.1 & $0.5-0.7$ & $0.6-1.4$ & - & Özden et al., 2002 \\
\hline Sir Dam Lake & Cyprinus carpio & - & - & - & - & - & 0.94 & Erdogrul et al., 2005 \\
\hline Marmara Sea & Anchovy & 0.83 & 9.64 & 4.52 & 16.60 & 14.11 & 63.30 & Coelhan et al., 2006 \\
\hline Marmara Sea & Horse Mackerel & 9.18 & 9.73 & 20.00 & 60.36 & 51.45 & 209.36 & Coelhan et al., 2006 \\
\hline Marmara Sea & Young Bluefish & 9.27 & 5.34 & 16.70 & 60.10 & 49.21 & 196.06 & Coelhan et al., 2006 \\
\hline İzmit Gulf & Whiting & nd-411.10 & nd-2008.07 & nd-265.00 & 396.82 & 477.67 & - & Çakıroğulları, 2006 \\
\hline İzmit Gulf & Horse Mackerel & nd-78.73 & nd-408.15 & 41.16 & 91.66 & 197.32 & - & Çakıroğulları, 2006 \\
\hline Istanbul Strait in the Marmara Sea & Mytilus galloprovincialis & $0.0615-0.409$ & $0.0432-0.271$ & $0.144-1.041$ & $0.00418-0.0503$ & $0.303-2.144$ & $1.039-5.4$ & Okay et al. 2009 \\
\hline $\begin{array}{l}\text { Hirfanl1 } \\
\text { Dam Lake }\end{array}$ & Atherina boyeri & 0.12 & 0.118 & 0.0911 & 0.187 & 0.273 & - & Çakıroğulları et al., 2011 \\
\hline Samsun Region of Turkey & Mugil cephalus & $0.093-0.2146$ & & 0.444 & $0.0288-0.0604$ & $\begin{array}{l}0.0431- \\
0.3116\end{array}$ & 1.784 & Aksoy et al. 2012 \\
\hline Samsun Region of Turkey & Salmo salar & $0.031-0.4915$ & & - & - & - & 0.9803 & Aksoy et al. 2012 \\
\hline
\end{tabular}




\section{References}

Ağca, İ. (2006): Konya'da satılan bazı balık türlerinde organoklorlu bazı pestisit kalıntılarının tayini. M.A. Thesis, Department of Biology, University of Selçuk.

Aksoy, A., Guvenc, D., Yavuz, O., Das, Y.K., Atmaca, E. (2012): Seasonal variation of polychlorinated biphenyls and organochlorine pesticide levels of sea and cultured farm fish in the Samsun Region of Turkey. Bulletin of Environmental Contamination and Toxicology, 88: 842849.

Aktumsek, A., Kara, H., Huseyin Kara, Nizamlioglu, F., Dinç, I. (2002): Monitoring of organochlorine pesticide residues in pikeperch, Stizostedion lucioperca L. in Beyşehir Lake (Central Anatolia). Environmental Technology, 23: 391-394.

Arslan, S. (2009): Bitkisel kaynaklı aktif karbon ile pestisit giderimi. M.A. Thesis, Department of Chemical Engineering, Yıldız Technical University.

Atamanalp, M., Yanık, T. (2001): Pestisitlerin Cyprinidae'lere toksik etkileri. Ege Journal of Fisheries \& Aquatic Science, 3(4): 555563.

Ayas, Z. (2007): Review on DDT and its residues in Turkey's wetlands. Journal of Environmental Biology, 28: 707-715.

Barlas, H., Coelhan, M., Bayat, C. (2000): Marmara Denizi'ndeki bazı balıklarda pestisit kirliliği düzeylerinin belirlenmesi. The Symposium the Marmara Sea 2000, 1112 November, İstanbul.

Başçınar, N., Gumrukcu, F., Okumus, I. (2008): Genç gökkuşağı alabalıklarında (Oncorhynchus mykiss Walbaum) yemleme stratejisi üzerine bir çalışma. Journal of Fisheries Sciences.com, 2: 224232.

Başpınar, H., Durmusoglu, E., Yıldırım, E.M. (2010): Türkiye'de tarım ilaçları üretim ve kullanımı.Turkey agricultural engineering
VII Technical Congress, 11-15 January 2010, Ankara.

Bocio, A., Llobet, J.M., Domingo, J.L., Corbella, J., Teixido, A., Casas, C. (2003): Polybrominated diphenyl ethers (PBDEs) in foodstuffs: Human exposure through the diet. Journal of Agricultural and Food Chemistry, 51: 3191-3195.

Boscolo, R., Cacciatore, F., Berto, D., Giani, M. (2007): Polychlorinated biphenyls in clams Tapes philippinarum cultured in the Venice Lagoon (Italy): Contamination levels and dietary exposure assessment. Food and Chemical Toxicology, 45: 1065-1075.

Bulut, S., Erdoğmuş, S.F., Konuk, M., Cemek, M. (2010): The Organochlorine pesticide residues in the drinking waters, of Afyonkarahisar, Turkey. Ekoloji, 74: 24-31.

Bulut, H., Tamer, A. (1996): Pestisit kullanımının azaltılması ile ilgili politika ve stratejiler. II. Symposium National Pest Eradication Chemicals, 18-20 November, Ankara.

Carvalho, F.P. (2006): Agriculture, pesticides, food security and food safety. Environmental Science and Policy, 9: 685692.

Chopra, A.K., Sharma, M.K., Chamoli, S. (2010): Bioaccumulation of organochlorine pesticides in aquatic system- an overview. Environmental Monitoring and Assessment, 173 (1-4): 905-916.

Coelhan, M., Strohmeier, J., Barlas, H. (2006): Organochlorine levels in edible fish from the Marmara Sea, Turkey. Environment International, 32: 775-780.

Çakırogulları, G.C. (2006): İzmit Körfezi'nde su, sediment, mezgit (Gadus merlangus L.1758) ve istavrit (Trachurus mediterraneus S.1868) balıklarında poliklorlu bifeniller ile DDT'nin saptanmas1. M.A. Thesis, Department of Seafood, Ankara University.

Çakırogulları, G.C., Kılıç, D., Uçar, Y. (2010): Levels of polychlorinated dibenzo-pdioxins, dibenzo-p-furans and polychlorinated biphenyls in farmed sea bass (Dicentrarchus labrax) and sea bream 
(Sparus aurata) from Turkey. Food Control, 21: 1245-1249.

Çakıroğulları, G.Ç., Uçar, Y., Kılıç, D. (2011): PCDD, PCDF and PCB contamination in Atherina boyeri (Risso, 1810) from Turkey. Food Control, 22: 67-71.

Delen, N., Durmuşoğlu, E., Güncan, A., Güngör, N., Turgut, C., Burçak, A. (2005) Türkiye'de pestisit kullanımı kalıntı ve organizmalarda duyarlılık azalışı sorunları. Turkey Agricultural Engineering Sixth Technical Congress, 3-7 January, Ankara.

DPMARA (Department of Publication of the Ministry of the Agriculture and Rurl Areas) (2011):

http:/turkiyeharitalar.blogspot.com/2011/1 1/turkiye-tarmsal-uretim-haritas.html (accessed January 30, 2013).

DPT (Turkish Prime Ministry-State Planning Organization) (2001): Eight Plan of Fiveyear Development. Chemical Industry (Pesticides) Special Commission Report, Ankara.

DPT (Turkish Prime Ministry-State Planning Organization) (2008): Ninth Plan of Development. Chemical Industry Special Commission, Fertilizer-Pesticide Working Group Report, Ankara.

Erdoğan, B.Y. (2010): Samsun'da yaygın olarak kullanılan pestisitlerin sağlığa ve çevreye etkileri. Alinteri, 19(B): 28-35.

Erkmen, B., Kolankaya, D. (2006): Determination of organochlorine pesticide residues in water, sediment and fish samples from the Meriç Delta, Turkey. International Journal of Environmental Analytical Chemistry, 86: 161-169.

Ezemonye, L.I., Ikpesu, T.O., Tongo,I. (2009): Distribution of endosulfan in water, sediment and fish from Warri river, Niger delta, Nigeria. African Journal of Ecology, 48: 248-254.

Flandysz, J., Wyrzykkowska, B., Worzocha, J., Barska, I., Garbacik-Wesolowska, A., Szefer, P. (2004): Organochlorine pesticides and PCBs in perch Perca Fluviatilis from the Odra/Oder River estuary, Baltic Sea. Food Chemistry, 87: $17-23$
FAO (Food and Agriculture Organization of the United Nations) (2002): International code of conduct on the distribution and use of pesticides (Release date 2010-9-25). http://www.fao.org/docrep/005/Y4544E/y4 544e00.htm (accessed January 30, 2013).

FAO (Food and Agriculture Organization of the United Nations) (2011): FAOSTAT. Pesticide Consumption 1990-2011, (Release date: 24 April 2012). http://faostat.fao.org/site/424/default.aspx\# ancor (accessed November 17, 2012).

Ferrante, M.C., Clausi, M.T., Meli, R., Fusco, G., Naccari, C., Lucisano, A. (2010): Polychlorinated biphenyls and organochlorine pesticides in European eel (Anguilla anguilla) from the Garigliano River (Campania region, Italy). Chemosphere, 78: 709-716.

Güvenc, D., Aksoy, A. (2007): Poliklorlu bifenillerin toksikolojisi. Veteriner Hekimler Derneği Dergisi, 78: 18-25.

Hamilton, D., Crossley, S. (2004): Pesticide Residues in Food and Drinking Water Human Exposure and Risks. John Wiley \& Sons Ltd., England.

Harvey, J., Harwell, L., Summers, J.K. (2008): Contaminant concentrations in whole-body fish and shellfish US estuaries. Environmental Monitoring and Assessment, 137: 403-412.

Kalyoncu, L., Agca, İ., Aktümsek, A. (2009): Some organochlorine pesticide residues in fish species in Konya, Turkey. Chemosphere, 74: 885-889.

Karakaya, M., Boyraz, N. (1992): G1da kirlenmesinde pestisitler ve korunma yolları. Çevre Dergisi, 4: 11-15.

Kaya, H. (2007): Atikhisar Barajı ve Sarıçay'da pestisit ve evsel kirliliğin araştırılması. M.A. Thesis, Department of Seafood, Çanakkale Onsekiz Mart University.

Kınık, Ö. (2002): Süt ve Ürünlerinde Pestisitler, TMMOB. Glda Mühendisliği Dergisi, 6: 31-38.

Kurşun, Ö., MOR, F. (2009): Aperspective on the potential health risks of dioxin in human 
food. Uludag University Journal of Faculty of Veterinary Medicine, 28: 43-47.

Liu, Z., Zhong, H., Tao, M., Yang, S., Wang, L., Liu, Y., Ma, D., He, Z. (2010): Organochlorine pesticides in consumer fish and mollusks of lianoning province, China: Distribution and human exposure implications. Archives of Environmental Contamination and Toxicology, 59: 444453.

Llobet Juan, M.., Domingo, J.L., Bocio, A., Casas, C., Teixido, A., Müller, L. (2003): Human exposure to dioxins through the diet in Catalonia, Spain: Carcinogenic and noncarcinogenic risk. Chemosphere, 50: 11931200.

Mathur, N., Pandey, G., Jain, G.C. (2010): Pesticides: A review of the male reproductive toxicity. Journal of Herbal Medicine and Toxicology, 4(1): 1-8.

Mead, P.S., Slutsker, L., Dietz, V., McCaig, L.F., Bresee, J.S., Shapiro, C., Griffin, P.M., Tauxe, R.V. (1999): Food-related illness and death in the United States. Emerging Infectious Diseases, 5: 607-625.

Okay, O.S., Karacık, B., Başak, S., Henkelmann, B., Bernhöft, S., Shcramm, K.W. (2009): $\mathrm{PCB}$ and $\mathrm{PCDD} / \mathrm{F}$ in sediments and mussels of the Istanbul Strait (Turkey). Chemosphere, 76: 159-166.

Okay, O.S., Karacık, B., Henkelmann, B., Shcramm, K.W. (2011): Distribution of organochlorine pesticides in sediments and mussels from the Istanbul strait. Environmental Monitoring and Assessment, 176: 51-65.

Özçelik, B., Uygun, Ü., Bayram, B. (2011): Handbook of Seafood Quality, Safety and Health Applications. In: Alasalvar, C., Shahidi, F., Miyashita, K., Wanasundara, U. (Eds.), Seafoods and Environmental Contaminants. Wiley-Blackwell Publishing Ltd., UK, pp. 303-311.

Özden, Ö., Kruse, R., Erkan, N. (2001): Vorkommen von Rükständen an Organochlor-Pestiziden, Nitromoschusverbindungen und Polychlorierten Biphenylen in türkischen
Fisdauerkonserven. Deutsche Tierärztliche Wochenschrift, 108: 159-163.

Özden, Ö., Kruse, R., Erkan, N. (2002): Bestimmung von Organochlor-Pestiziden und Polychlorierten Biphenylen in Miesmuscheln. Deutsche LebensmittelRundschau, 98: 215-220.

Saler, S. (2006): Pestisitlerin akuatik omurgasizlar üzerine etkisi. Sümder Dergisi, 25-26: 2832.

Seyran, A., Erişir, M. (2008): Poliklorlu bifeniller ve sağllk üzerine etkileri. Firat University Veterinary Journal of Health Sciences, 22 (1): 33-40.

Smith, A.G., Gangolli, S.D. (2002): Organochlorine chemicals in seafood: Occurrence and health concerns. Food and Chemical Toxicology, 40: 767-779.

Storelli, M.M. (2008): Potential human health risks from metals $(\mathrm{Hg}, \mathrm{Cd}$ and $\mathrm{Pb})$ and polychlorinated biphenyls (PCBs) via seafood consumption: Estimation of target hazard quotients (THQs) and toxic equivalents (TEQs). Food and Chemical Toxicology, 46: 2782-2788.

Syasina, I. G. (2003): Organochlorine pesticides in fishes and mollusks from lower reaches of the Tumen River and of the contiguous part of Peter the Great Bay (Sea of Japan). Ecology, 29: 23-30.

Sweilum, M.A. (2006): Effect of sublethal toxicity of some pesticides on growth parameters, haematological properties and total production of Nile tilapia (Oreochromis niloticus L.) and water quality of ponds. Aquaculture Research, 37: 1079-1089.

Wilson, J.S., Tsunehiro, O. (2004): To Spray or not to spray: Pesticides, banana exports, and food safety. Food Policy, 29: 131-146.

Takazawa, Y., Tanaka, A., Shibata, Y. (2008): Organochlorine pesticides in muscle of rainbow trout from remote Japanese Lake and their potential risk on human health. Water, Air and Soil Pollution, 187: 31-40.

Tarım ve Gıda Paneli Son Rapor (2003): Tübitak vizyon 2023 bilim ve teknoloji öngörüsü 
projesi.

http://www.tubitak.gov.tr/tubitak content files/vizyon $2023 / \mathrm{tg} /$ tarimgida son surum. pdf. (accesed 08.02.2013)

Topçu Sulak, M. (2012): Pestisitlerin taşınım süreçleri ve çevresel etkileri. I. Tarım Sağlığı ve Güvenliği Sempozyumu. 6-7 April 2012, Şanlıurfa.

Turgut, C. (2003): The contamination with organochlorine pesticides and heavy metals in surface water in Küçük Menderes River in Turkey, 2000-2002. Environment International, 29: 29-32.

Turkish Agriculture Industry Report (2010): Republic of Turkey Prime Ministry Invesment Support and Promotion Agency of Turkey. Date: July 2010. http://www.invest.gov.tr/en-

US/infocenter/publications/Documents/AG RICULTURE.INDUSTRY.PDF (accesed 08.02.2013)

Turkish Food Codex (2009): Communique on maximum residue limits of pesticides that are allowed in foodstuffs. In: Official Gazette No. 27449. Date: 31.12. 2009. Ankara, Turkey: Ministry of Agriculture (in Turkish).
Turkish Food Codex (2011): Registration of contaminants. In: Official Gazette No. 28157. Date: 29.12. 2011. Ankara, Turkey: Ministry of Agriculture (in Turkish).

Turkish Statistical Institute (TUIK) (2011): Agricultural Gensus Statistics. (Release date: 26 November 2012). http://www.tuik.gov.tr/Gosterge.do?id=36 30\&metod=IlgiliGosterge (accesed 08.02.2013)

Uluocak, B., Egemen, H.Ö. (2005): İzmir ve Aliağa Körfezinde mevsimsel olarak avlanan bazı ekonomik balık türlerinde organik klorlu pestisit kalıntılarının araştırılması. Ege Üniversitesi Su Ürünleri Dergisi, 22(1-2): 149-160.

Yeşil, S., Ögür, E. (2011): Zirai mücadelede pestisit kullanımının Türkiye ve Konya ölçeğinde değerlendirilmesi ve pestisit kullanımının olası sakıncaları. I. Konya Kent Sempozyumu, 26-27 November 2011, Konya. 